\title{
THE MEASUREMENT OF EXTRACELLULAR FLUID IN MAN BY MEANS OF A CONSTANT INFUSION TECHNIQUE ${ }^{1}$
}

\author{
By IRVING L. SCHWARTZ, DAVID SCHACHTER, AND NORBERT FREINKEL \\ (From the Department of Physiology, New York University College of Medicine, \\ New York City)
}

(Received for publication April 8, 1949)

The principle substances in use to date as indicators of the extracellular water volume do not fulfill the basic requirement of exclusive distribution in the extracellular space.

Sodium is normally present in erythrocytes (1-3), striated muscle $(4,5)$, spinal cord, cartilage and bone $(4,6,7)$. Chloride penetrates erythrocytes, connective tissue, pyloric mucosa, testes, salivary glands and cells of the central nervous system $(6,8)$. Bromide interchanges freely with chloride in all tissues except the central nervous system $(9,10)$ and therefore probably shares with chloride the property of cell penetration. Thiocyanate is bound to lipid and penetrates erythrocytes, gastric mucosa and other tissues $(7,11-14)$ and in bacteremia, spotted fever and malaria, and following artificial hyperpyrexia thiocyanate space may approach the value for total body water (15-17). Apparently, therefore, these ions may be used in normal individuals only for approximation of the volume of extracellular water, and in pathological states altered cellular permeability may invalidate even such approximate measurements.

Inulin, sucrose and mannitol are distributed throughout a consistently lower fraction of body water than are the electrolytes (18-23). Although these substances appear to circumvent the problem of cell penetration, they raise the question of how may plasma-interstitial fluid equilibrium be assured in the face of rapid elimination, slow diffusion, or both?

Any substance distributed in some fixed fraction of the body water will approach a uniform or equilibrium concentration throughout that compartment under conditions where its rate of infusion (in milligrams per minute) and its clearance or specific rate of removal (in milligrams per min-

1 Aided by grants from the Commonwealth Fund and the U. S. Public Health Service.

${ }^{2}$ National Institutes of Health Postdoctorate Research Fellow. ute per unit plasma concentration) remain constant for a sufficiently long period of time. After uniform distribution is attained, if the infusion is stopped and the total amount of the substance present in the body water is recovered quantitatively in the urine, its volume of distribution is the amount recovered divided by the equilibrium plasma water concentration. The use of inulin in the constant infusion method in dog and man has been reported in a preliminary paper (23), and more definitive data are available in the dog (24). The studies described here were undertaken to supplement our preliminary observations and to develop a standard constant infusion method for the measurement of inulin space in man.

\section{METHODS}

Twenty-nine studies were carried out in ten normal male subjects ranging from 21 to 55 years of age, and in five elderly male patients with congestive heart failure ${ }^{3}$ ranging from 45 to 60 years of age. In six of these studies a single intravenous injection of 50 to $75 \mathrm{cc}$. of 10 per cent inulin was given from a syringe calibrated at $20^{\circ}$ centigrade with mercury or water at arbitrary marks. For the next 24 hours samples of blood and serial urine collections were obtained.

In the remaining 24 studies a priming injection of inulin was followed by a constant sustaining infusion for 1.7 to 30 hours. Assuming a distribution volume of 18 per cent of body weight, the prime was calculated to yield a plasma concentration of 10 to $30 \mathrm{mg}$. per cent and the concentration of sustaining infusion was calculated on an assumed filtration rate. Inulin solutions were made up in sterile isotonic saline except those for the cardiac patients where 5 per cent dextrose in distilled water was used. Constancy of the infusion rate in the first five studies was maintained by adjusting a Murphy drip every five to ten minutes. In all other experiments this was achieved with a constant infusion pump. The rate of

3 The five patients with congestive heart failure were subjects who had been infused with inulin during the course of studies conducted by Dr. David Baldwin, Dr. Herman Villareal, and Dr. Jonas Sirota, who kindly allowed us to utilize these infusions in order to determine the inulin space. 
infusion used was $1.3 \mathrm{cc}$. per minute in all normal subjects and $0.3 \mathrm{cc}$. per minute in the cardiac patients. Calibration of this pump in successive 15,30 and 60 minute periods revealed variation of less than 1 per cent at the higher rate and less than 3 per cent at the lower rate.

Varying lengths of infusion were utilized in the same individual whenever possible in order to determine the minimal time for equilibration of plasma water and interstitial fluid and to observe the reproducibility of the measurement of inulin space.

No preparation of the subject was made other than an attempt to maintain adequate and uniform hydration with a urine flow of 2 to $4 \mathrm{cc}$. per minute during the infusion. Before the priming injection a control blood and timed urine sample were obtained for determination of plasma blank concentration, $B_{0}$, and the rate of urinary excretion of inulinoid blank, $U_{0} V$, which quantities were subtracted respectively from subsequent plasma concentrations and from the total inulin excretion during the post-infusion recovery period. Two or more blood samples were taken during the infusions to ascertain constancy of the plasma concentration. Shortly before stopping the infusion, the bladder was catheterized and a final blood sample was drawn. The bladder was washed well with isotonic saline and air. At completion of the wash-out the infusion was discontinued and all subsequent urine was collected in 0.5 to six hour long periods for the next 22 to 48 hours. In the subjects used for repeated studies blood samples were drawn at periodic intervals during this post-infusion period so that the decrement in plasma concentration with time might be compared in the same individual following varying periods of infusion. Blood samples were drawn from an antecubital vein using 0.1 cc. Liquaemin (Hoffmann-La Roche) per $10 \mathrm{cc}$. of whole blood as an anticoagulant. The patients with congestive heart failure were given $2 \mathrm{cc}$. of mercupurin intravenously shortly after the infusion was discontinued.

Our present criterion for equilibrium distribution of inulin throughout the extracellular fluid is attainment of a maximal and constant volume of distribution as the duration of infusion is successively increased in the same individual.

In some subjects, thiocyanate, bromide and $\mathrm{Na}^{24}$ spaces were also determined by the single injection method. Blood samples were drawn after one hour for thiocyanate and after three to four hours for bromide and $\mathrm{Na}^{24}$ determinations. Thiocyanate was determined by the method of Crandall and Anderson (11) adapted to the Beckman Spectrophotometer, model DU. Readings were made at a wave length of $460 \mathrm{~m} \mu$ using cuvettes with a light path of $10 \mathrm{~mm}$. Bromide was determined by the method of Brodie and Friedman (25), inulin by Harrison's modification (26) of the method of Alving, Rubin and Miller (27), and $\mathrm{Na}^{24}$ was measured with a Geiger-Müller counter. The plasma concentrations of inulin, thiocyanate, bromide and sodium are corrected for a plasma water content of 94 per cent and the concentrations of thiocyanate, bromide, and $\mathrm{Na}^{24}$ are corrected for the Donnan factor $k$ : for thiocyanate and bromide, $k=1.05$ and for
$\mathrm{Na}^{24}, k=0.95$. No correction was made for plasma protein or lipoid binding of thiocyanate.

Urines were yeasted and precipitated in the same manner as the plasma. In some cases urines were yeasted both before and after dilution to a $U / P$ ratio of 1 , in which case the determinations compared within 2 per cent. Analyses were checked frequently by recoveries of known amounts of inulin added to water and plasma. The $\mathrm{pH}$ of the plasma filtrate was kept at or below 7 .

The rate of excretion of inulinoid blank, $U_{0} V$, was determined in 30 successive one to three hour urine periods for eight to 24 hours in four normal subjects at urine flows varying from $0.4 \mathrm{cc}$. per minute to $10 \mathrm{cc}$. per minute, both in the fasting state and during unrestricted dietary intake. Blank excretion showed no relation either to urine flow or time after eating. The average $U_{0} V$ of 53 periods including the above, was $0.16 \mathrm{mg}$. per minute with a standard deviation of $\pm 0.055 \mathrm{mg}$. per minute. Inulin space errors due to variation in $\mathrm{U}_{0} \mathrm{~V}$ become less significant as the equilibrium plasma concentration is elevated. In a normal subject with a plasma concentration of $30 \mathrm{mg}$. per cent and an inulin space of 10 liters, the average error to be expected from variations in $\mathrm{U}_{0} \mathrm{~V}$ during a 15 hour recovery period is 1.7 per cent, and the error to be expected from complete neglect of $U_{0} V$ is 4.8 per cent.

\section{RESULTS}

Equilibration Time. The inulin volume of distribution was not increased significantly when the infusion was extended beyond 4.5, 3.3, 3.8, 7.5 and seven hours in five normal subjects, respectively, as compared with a minimal infusion period of 1.7 hours (Table I). In one of these subjects determinations were made with infusion periods varying from 1.7 to 17.5 hours. Inulin space increased asymptotically with the duration of infusion approaching a limiting value of 13.7 liters, as calculated by a first order differential equation applied to a curve drawn through the observed points (Figure 1). In this subject the inulin space after five hours of infusion was 95 per cent of the limiting value. The curves of declining plasma concentrations following cessation of infusion at $4.5,5.5$ and 17.5 hours were virtually superimposable when plotted on the same scale (Figure 2). We conclude that for all practical purposes plasma-interstitial fluid equilibrium was established in this subject by five hours.

After a single intravenous injection of inulin the curve of plasma concentration plotted against time shows two phases: an early rapid decrement followed by a period of more gradual decrement. 


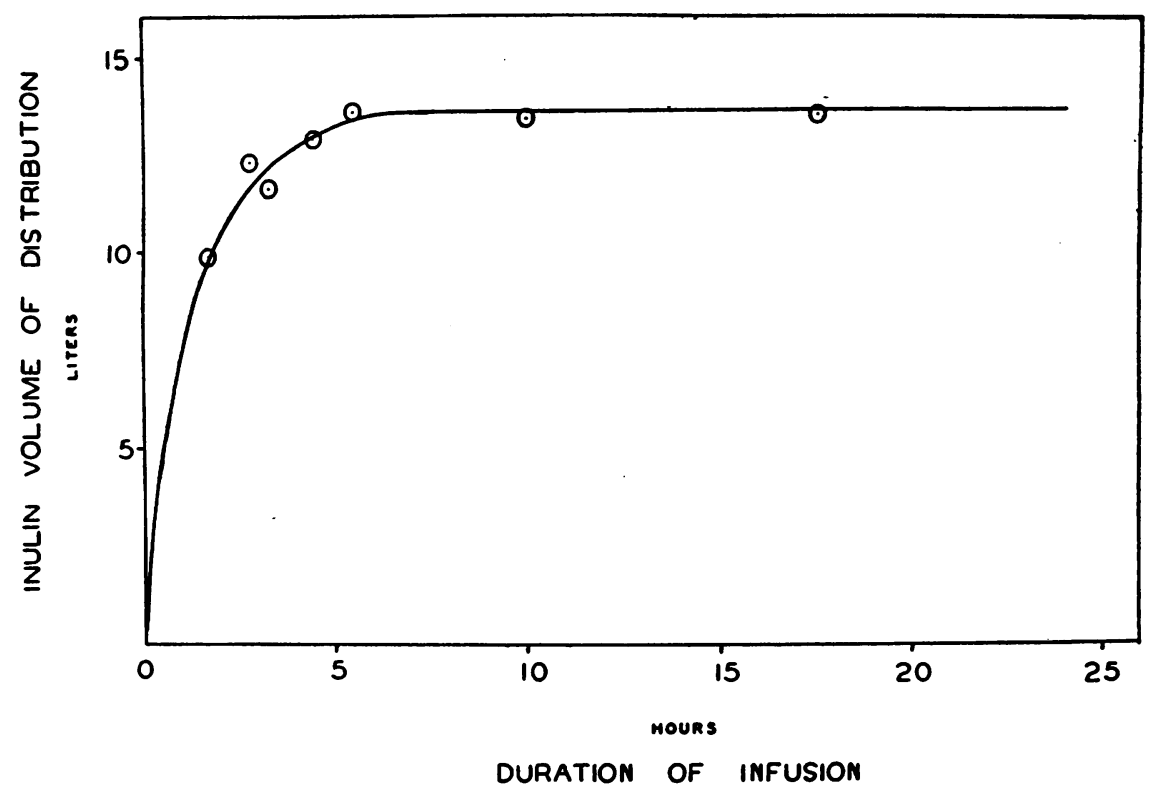

Fig. 1. Inulin Volume of Distribution Determined After Various Periods of INFUSION IN THE SAME INDIVIDUAL

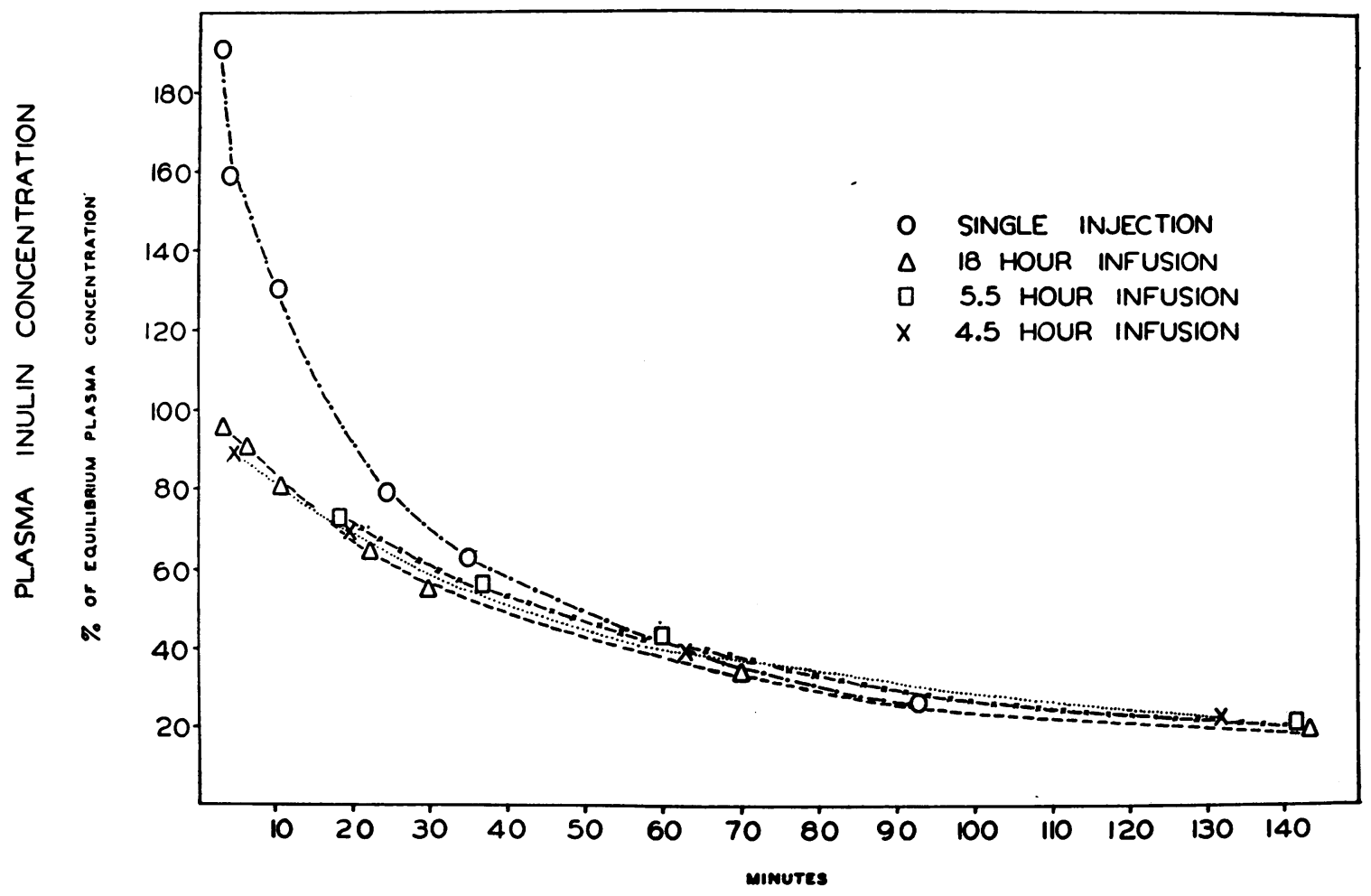

TIME AFTER STOPPING INFUSION

Fig. 2. Concentration of Inulin in Plasma Following a Single Injection and Infusions of $4.5,5.5$ AND 17.5 Hours

For the single injection the equilibrium plasma concentration was calculated as the amount of inulin injected divided by the inulin volume of distribution as determined previously by the infusion method. 
TABLE I

Volume of distribution of inulin, thiocyanate, bromide and radioactive sodium in man

\begin{tabular}{|c|c|c|c|c|c|c|c|c|c|c|c|c|c|c|}
\hline \multirow{3}{*}{ Subject } & \multirow{3}{*}{ Age } & \multirow{3}{*}{ Date } & \multirow{3}{*}{ Weight } & \multirow{3}{*}{$\begin{array}{l}\text { Duration } \\
\text { of equili- } \\
\text { brating } \\
\text { infusion }\end{array}$} & \multirow{3}{*}{$\begin{array}{c}\text { Equilibrium } \\
\text { inulin con- } \\
\text { centration in } \\
\text { plasma water }\end{array}$} & \multirow{3}{*}{$\begin{array}{l}\text { Duration } \\
\text { of urin- } \\
\text { ary re- } \\
\text { covery }\end{array}$} & \multicolumn{8}{|c|}{ Volume of distribution } \\
\hline & & & & & & & \multirow{2}{*}{ Inulin } & \multirow{2}{*}{$\begin{array}{l}\text { Thiocy- } \\
\text { anate }\end{array}$} & \multirow{2}{*}{ Bromide } & \multirow{2}{*}{$\begin{array}{l}\text { Radio- } \\
\text { active } \\
\text { sodium }\end{array}$} & \multicolumn{4}{|c|}{ Percentage of body weight } \\
\hline & & & & & & & & & & & Inulin & $\begin{array}{l}\text { Thiocy- } \\
\text { anate }\end{array}$ & Bromide & $\begin{array}{l}\text { Radio-' } \\
\text { active } \\
\text { sodium }\end{array}$ \\
\hline I. S. & $\begin{array}{c}y r s . \\
29\end{array}$ & \begin{tabular}{|c|}
$10 / 26 / 48$ \\
$11 / 13 / 48 *$ \\
$8 / 30 / 48$ \\
$9 / 6 / 48$ \\
$10 / 16 / 48$ \\
$8 / 24 / 48$
\end{tabular} & $\begin{array}{c}\text { kg. } \\
86.4 \\
86.2 \\
87.3 \\
86.9 \\
86.5 \\
88.5\end{array}$ & $\begin{array}{r}\text { hours } \\
1.7 \\
2.8 \\
3.3 \\
4.5 \\
5.5 \\
17.5\end{array}$ & \begin{tabular}{c|} 
mg. per cent \\
16.0 \\
32.9 \\
16.9 \\
25.8 \\
24.1 \\
13.7
\end{tabular} & $\begin{array}{l}\text { hours } \\
24 \\
24 \\
23 \\
22 \\
36 \\
24\end{array}$ & \begin{tabular}{r|} 
liters \\
9.9 \\
12.3 \\
11.6 \\
12.9 \\
13.6 \\
13.5
\end{tabular} & $\begin{array}{l}\text { liters } \\
19.3\end{array}$ & $\begin{array}{l}\text { liters } \\
21.4\end{array}$ & $\begin{array}{l}\text { liters } \\
22.7\end{array}$ & $\begin{array}{c}\text { per cent } \\
11.4 \\
14.3 \\
13.3 \\
14.9 \\
15.8 \\
15.3\end{array}$ & $\begin{array}{l}\text { per cent } \\
22.2\end{array}$ & $\begin{array}{c}\text { per cent } \\
24.8\end{array}$ & $\begin{array}{c}\text { per cent } \\
26.4\end{array}$ \\
\hline D.S. & 21 & $\begin{array}{r}10 / 22 / 48 \\
8 / 28 / 48 \\
8 / 11 / 48\end{array}$ & $\begin{array}{l}72.7 \\
72.2 \\
72.5\end{array}$ & $\begin{array}{l}3.3 \\
8.3 \\
26\end{array}$ & $\begin{array}{l}18.3 \\
22.8 \\
16.1\end{array}$ & $\begin{array}{l}26 \\
34 \\
28\end{array}$ & $\begin{array}{l}12.1 \\
12.2 \\
12.4\end{array}$ & 17.4 & & & $\begin{array}{l}16.6 \\
16.8 \\
17.1\end{array}$ & 24.1 & & 用 \\
\hline N.F. & 24 & $\begin{array}{l}11 / 5 / 48 \\
11 / 12 / 48\end{array}$ & $\begin{array}{l}73.3 \\
73.4\end{array}$ & $\begin{array}{l}3.8 \\
7.0\end{array}$ & $\begin{array}{l}25.9 \\
28.5\end{array}$ & $\begin{array}{l}24 \\
22\end{array}$ & $\begin{array}{l}10.4 \\
10.9\end{array}$ & 15.9 & 15.1 & 19.8 & $\begin{array}{l}14.2 \\
14.9\end{array}$ & 21.6 & 20.6 & 27.0 \\
\hline G. F. & 51 & $\begin{array}{l}9 / 22 / 48 \\
6 / 24 / 48 \\
9 / 29 / 48\end{array}$ & $\begin{array}{l}84.5 \\
83.5 \\
84.6\end{array}$ & $\begin{array}{r}4.7 \\
7.5 \\
15.3\end{array}$ & $\begin{array}{l}27.1 \\
22.5 \\
22.6\end{array}$ & $\begin{array}{l}21.5 \\
22.5 \\
25\end{array}$ & $\begin{array}{l}12.0 \\
13.2 \\
13.5\end{array}$ & $\begin{array}{l}18.1 \\
20.7\end{array}$ & 17.8 & 22.4 & $\begin{array}{l}14.2 \\
15.8 \\
16.0\end{array}$ & $\begin{array}{l}21.6 \\
24.5\end{array}$ & 21.3 & 26.4 \\
\hline M. P. & 43 & $\begin{array}{l}6 / 17 / 48 \\
6 / 20 / 48\end{array}$ & $\begin{array}{l}63.2 \\
63.0\end{array}$ & 17.0 & $\begin{array}{c}8.64 \\
18.2\end{array}$ & $\begin{array}{l}12 \\
17\end{array}$ & $\begin{array}{l}10.4 \\
10.6\end{array}$ & 17.0 & & & $\begin{array}{l}16.5 \\
16.8\end{array}$ & 26.8 & & \\
\hline D. C. & 38 & $6 / 29 / 48$ & 63.7 & 8.5 & 10.6 & 12.4 & 11.5 & 16.1 & & & 18.0 & 25.3 & & \\
\hline V.S. & 50 & $7 / 7 / 48$ & 62.3 & 16.5 & 4.9 & 17 & 10.1 & 17.2 & 16.0 & & 16.1 & 27.5 & 25.7 & \\
\hline J. T.† & 52 & $5 / 12 / 48$ & 53.3 & 29 & 10.3 & 23 & 16.3 & & & & 30.5 & & & \\
\hline F. C.t & 49 & $9 / 19 / 48$ & 61.0 & 26 & 18.6 & 31 & 19.0 & & & & 31.2 & & & \\
\hline T. N.† & 67 & $10 / 5 / 48$ & 62.8 & 26.5 & 9.8 & 48 & 24.8 & & & & 39.4 & & & \\
\hline A. D. & 68 & $10 / 19 / 48$ & 60.0 & 28 & 16.4 & 45 & 11.5 & & & & 18.5 & & & \\
\hline T. P.† & 60 & $11 / 2 / 48$ & 70 & 30 & 8.1 & 43 & 15.9 & & & & 22.7 & & & \\
\hline
\end{tabular}

* No catheterization, bladder emptied by spontaneous voiding when infusion stopped.

† Patients with congestive heart failure: J. T., Rheumatic heart disease, ++ peripheral edema, enlarged tender liver, moist rales at both lung bases. F. C., Rheumatic heart disease, +++ peripheral edema, enlarged tender liver, right pleural effusion. T. N., Corpulmonale, ++++ peripheral edema, advanced congestive heart failure. A. D., Arteriosclerotic heart disease, no pheripheral edema, dyspneic, orthopneic, depressed breath sounds and moist rales at both lung bases. T. P., Arteriosclerotic heart disease, generalized anasarca on admission to the hospital, digitalized on the ward with good response, + edema on $11 / 3 / 48$ when infusion stopped.

Two similar phases are seen in the falling curve observed after stopping a constant intravenous infusion, but the initial period of rapid decrement is less prolonged. The duration of this initial phase decreases progressively with increasing durations of infusion until a minimum is reached at equilibration time. Following longer periods of infusion, the curves are identical (Figure 2).

Estimation of equilibration time by serial determinations on the same individual was not feasible in patients with congestive heart failure.
In Patient F. C., who had extensive edema and a right pleural effusion, equilibrium between pleural fluid and plasma was not achieved 20 hours after starting the sustaining infusion. Simultaneous pleural fluid and plasma water inulin concentrations were $13.0 \mathrm{mg}$. per cent and $17.7 \mathrm{mg}$. per cent respectively.

Recovery of inulin in urine after single injection. When 5 to $7 \mathrm{gm}$. of inulin were injected into six normal subjects, urinary recovery accounted for $98.0,97.6,91.5,94.4,98.7,101$ per cent of the 
TABLE II

Quantitative urinary recovery of injected inulin

\begin{tabular}{|c|c|c|c|c|}
\hline \multirow{2}{*}{ Subject } & \multirow{2}{*}{$\begin{array}{c}\text { Amount of } \\
\text { inulin in- } \\
\text { jected }\end{array}$} & \multicolumn{3}{|c|}{ Urine collection } \\
\hline & & $\begin{array}{l}\text { Time after } \\
\text { injection }\end{array}$ & $\underset{\text { Total amount }}{\text { recovered }}$ & $\begin{array}{c}\text { Total amount } \\
\text { injected }\end{array}$ \\
\hline D. S. & $\begin{array}{l}\text { mg. } \\
7285\end{array}$ & $\begin{array}{c}\text { hours } \\
1.6 \\
4.6 \\
8.9 \\
18 \\
20\end{array}$ & $\begin{array}{c}\text { per cent } \\
64 \\
87.5 \\
96.5 \\
99.4 \\
100\end{array}$ & $\begin{array}{r}\text { per cent } \\
98.0\end{array}$ \\
\hline N. F. & 5942 & $\begin{array}{r}0.5 \\
1.1 \\
1.7 \\
2.2 \\
4.7 \\
22.3 \\
23.4\end{array}$ & $\begin{array}{c}36.8 \\
52.4 \\
63.1 \\
69.0 \\
84.9 \\
99.8 \\
100\end{array}$ & 97.6 \\
\hline D. L. & 2613 & $\begin{array}{r}0.6 \\
1.3 \\
1.8 \\
2.5 \\
4.4 \\
7.3 \\
10.2 \\
19.4 \\
25.4 \\
28.6\end{array}$ & $\begin{array}{l}37.5 \\
53.6 \\
66.9 \\
74 \\
87.6 \\
96 \\
98.6 \\
99 \\
100 \\
100\end{array}$ & 91.5 \\
\hline I. S. & 5340 & $\begin{array}{r}1.4 \\
2.3 \\
3.4 \\
4.4 \\
6.4 \\
9.4 \\
18.5 \\
26.3 \\
31.4\end{array}$ & $\begin{array}{c}65.2 \\
71.8 \\
82.4 \\
87.0 \\
92.0 \\
95.6 \\
98.0 \\
99.0 \\
100\end{array}$ & 94.4 \\
\hline M. R. & 5030 & $\begin{array}{l}3.3 \\
5.4 \\
13.4 \\
15.8 \\
24\end{array}$ & $\begin{array}{c}83.6 \\
92.4 \\
99.2 \\
99.5 \\
100\end{array}$ & 98.7 \\
\hline H. L. & 6280 & 24 & 100 & 101 \\
\hline
\end{tabular}

amount injected. Over 95 per cent of the total amount recovered was excreted in nine hours (Table II).

Recovery time following infusion of inulin. In the normal subjects, analysis of the cumulative post-infusion recoveries shows that over 95 per cent of the ultimate total recovery was collected at the end of 12 hours, and over 98 per cent of the ultimate recovery was collected at the end of 15 hours (Figure 3 ). In the patients with edema of congestive failure the quantity of inulin recovered in 22 to 30 hours was 98 per cent of the ultimate total amount recovered in 48 to 72 hours.

Inulin volume of distribution. In the seven normal subjects the inulin space ranged from 14 to 18 per cent of body weight, with an average of 16.2 per cent. No attempt was made to correlate inulin space with body surface area, but it was noted that higher values in terms of per cent of body weight were obtained in lean individuals. Precision of the measurement may be judged by the reproducibility of values in repeated determinations on the same individual. In the five subjects in whom long infusions (exceeding five hours) were repeated, the largest inulin space difference observed in successive measurements was 0.5 liters and the smallest difference was 0.1 liters.

Inulin space in five patients with congestive heart failure ranged from 18.5 to 39.4 per cent of body weight and correlated directly with the degree of edema, as judged clinically. These values, however, may still be low because of failure to attain equilibrium despite infusion for 26 to 30 hours.

Comparison with other methods. Simultaneous thiocyanate, bromide and $\mathrm{Na}^{24}$ spaces were all significantly higher than inulin space (Table I).

\section{DISCUSSION}

That inulin does not penetrate cells seems probable $a$ priori because of its high molecular weight and elongate configuration $(28,29)$. It does not enter erythrocytes $(30,31)$, bile $(21,32)$, gastric juice $(31,32)$ or cells of the renal tubule $(30$, 33 ), and no enzymes are known to be present in man which are capable of hydrolyzing it $(30,33)$. It is neither metabolized nor stored in the body as evidenced by its rapid quantitative urinary excretion (Table II). Our six urinary recoveries of inulin are in accord with the observations of others (34-36).

Our present values for the volume of distribution of inulin average 16.2 per cent of body weight as compared with significantly higher values obtained for the volume of distribution of thiocyanate, bromide and $\mathrm{Na}^{24}$. The volume of distribution of mannitol is estimated to be 16 per cent of body weight in man when allowance is made for the metabolism of this compound (20). It appears, therefore, that inulin and mannitol occupy some constant fraction of body water which is smaller than the fraction occupied by any of the electrolytes used for the measurement of extra- 


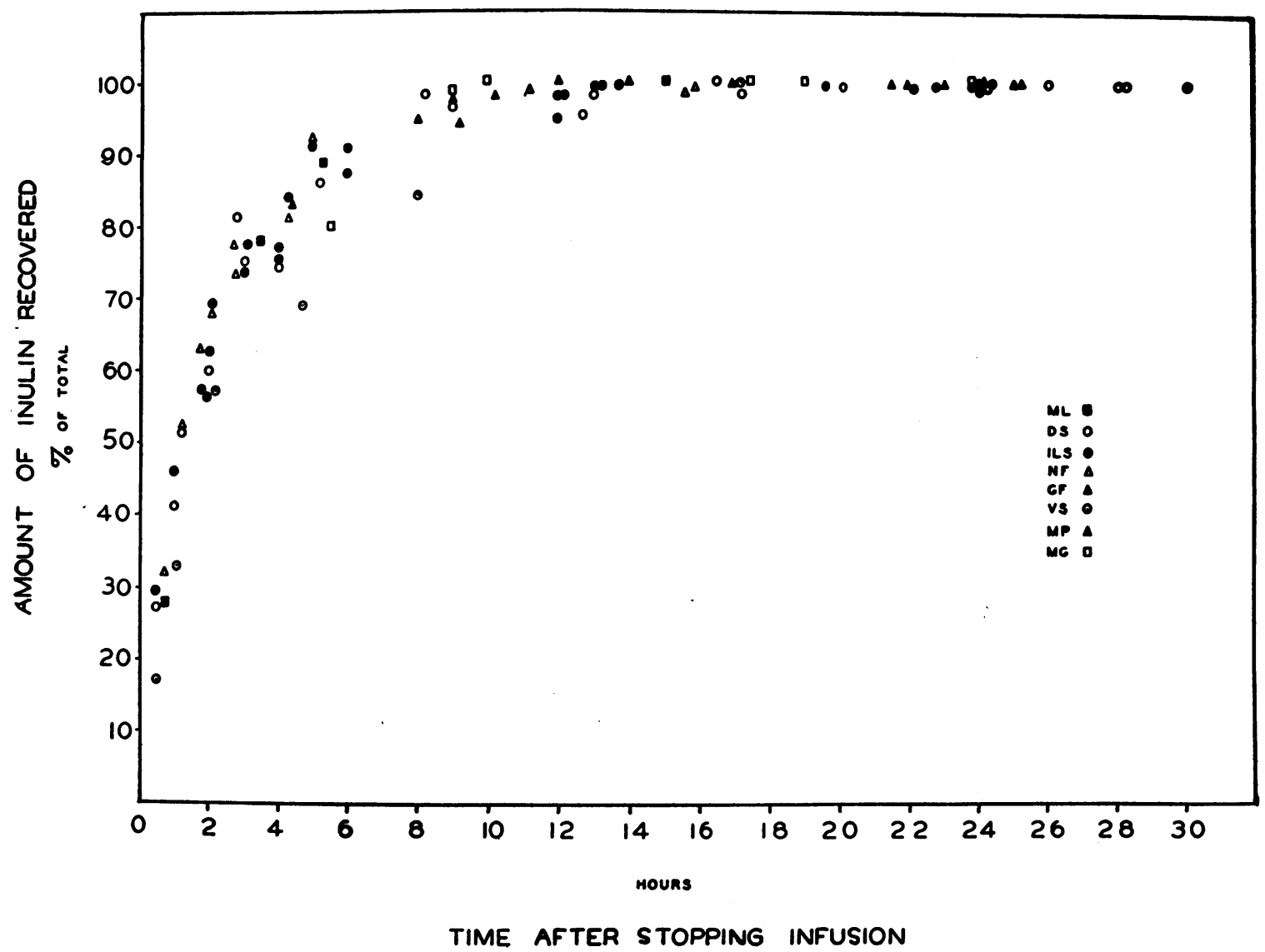

Fig. 3. Rate of Urinary Recovery of Inulin Following Cessation of InUlin Infusion in Eight Normal Subjects

cellular fluid $(4,7-10,12,14,37-40)$. This smaller fraction of the body water conforms better with the values to be predicted from recent total body water measurements in man $(41,42)$. For these reasons we believe that the volume of distribution of inulin better approximates the true volume of extracellular fluid than the thiocyanate, bromide, chloride or $\mathrm{Na}^{24}$ space.

A study of the transcapillary movement of inulin indicates that the time required to establish equilibrium between plasma and interstitial fluid might be reduced if a higher priming dose relative to the sustaining infusion were used. Berger, Farber and Earle (43) have pointed to the importance of adequately estimating the filtration rate, and have shown that only one to one and one-half hours are required to achieve constant plasma inulin levèls in normal subjects. Our experience confirms this point. It appears, therefore, that variations in plasma concentration falling within the analytic error are compatible with incomplete saturation of remote phases of the interstitial fluid.

Extracellular fluid expansion increases the time required to establish plasma-interstitial fluid equilibrium and the time required for recovery of inulin in the urine. This constitutes a serious limitation of the application of the measurement of inulin space in edematous states, especially where there are large accumulations of pleural or peritoneal fluid into which inulin must diffuse. In these cases a similar infusion technique utilizing more rapidly diffusible substances may prove to be more suitable.

Failure of equilibration between plasma and interstitial fluid may result from variation of the filtration rate, the extracellular fluid volume or the infusion rate. For example, in Subject D. S. a pyrogenic reaction accompanied by an elevated 
filtration rate was encountered, and the calculated inulin space was higher by 1.4 liters than any other observation of this subject. Infusion of saline over long periods of time may alter the filtration rate or the extracellular fluid volume; therefore, 5 per cent dextrose in distilled water is a preferable diluent for inulin in prolonged infusions.

The presence of inulin in the renal tubules, collecting ducts, pelves and ureters at the moment of stopping the infusion results in an error which raises the calculated inulin volume of distribution. This dead space error varies in the same direction as the renal delay time and inversely with the rate of urine flow at the time of stopping the infusion; however, if urine leaves the renal pelves and ureters in intermittent spurts, an assumed relationship between the renal delay time and rate of urine flow may not afford a reliable correction of the inulin space in this method. The data presented here are not corrected for the renal dead space; but during the infusions in our normal subjects the urine flow was maintained at 2 to $4 \mathrm{cc}$. per minute in order to minimize this source of error. In patients with congestive failure, where the rate of urine flow is less than $1 \mathrm{cc}$. per minute, the renal dead space error may increase the calculated inulin space considerably. Direct measurement of the volume and concentration of the urine contained in the renal calyces, pelves and ureters of a dog accounted for 7.6 per cent of a previously determined inulin space. The rate of urine flow in this animal at the time the ureters and renal blood vessels were ligated was $0.8 \mathrm{cc}$. per minute (31).

The determination of inulin space in patients with edema and oliguria involves both the error from failure to effect equilibrium distribution of inulin and the error of the renal dead space. Although these errors tend to cancel each other to some degree, it is necessary in such cases to prove that plasma and interstitial fluid concentrations are the same by analysis of the edema fluid and to minimize the renal dead space error by instituting diuresis shortly before the infusion is stopped.

\section{SUMMARY}

1. In normal human subjects after a priming dose and a constant intravenous infusion of inulin : (a) A period of five hours is sufficient for essentially homogenous distribution of inulin throughout the volume of distribution.

(b) A period of 12 to 15 hours is required for quantitative urinary recovery of the inulin present in the body after the infusion has been discontinued.

2. The volume of distribution of inulin, determined by dividing the total amount recovered in the urine after stopping the infusion by the concentration in plasma water at equilibrium, averages 16.2 per cent of body weight. This value is significantly lower than the volumes of distribution of thiocyanate, bromide and $\mathrm{Na}^{24}$ determined simultaneously with the inulin space or in successive experiments.

3. Inulin space is reproducible in the same individual with different durations of infusion in excess of the minimum infusion time required for equilibrium.

4. The calculated inulin volume of distribution in five patients with congestive heart failure ranged from 18.5 to 39.4 per cent of body weight and correlated qualitatively with the observed degree of edema.

5. Extensions and limitations of the constant infusion principle for the determination of extracellular fluid volume are discussed.

\section{ACKNOWLEDGMENTS}

We gratefully acknowledge the generous counsel of Dr. Domingo Gomez and the assistance of Dr. Ernest Breed and Miss Babette Solomon. We are indebted to Dr. Eugene Berger of the Third (New York University) Research Service, Goldwater Memorial Hospital, for the bromide analyses.

\section{BIBLIOGRAPHY}

1. Cohn, W. E., and Cohn, E. T., Permeability of red corpuscles of the dog to sodium ion. Proc. Soc. Exper. Biol. \& Med., 1939, 41, 445.

2. Streef, G. M., Sodium and calcium content of erythrocytes. J. Biol. Chem., 1939, 129, 661.

3. Kerr, S. E., Studies on the inorganic composition of blood. J. Biol. Chem., 1937, 117, 227.

4. Harrison, H. E., Darrow, D. C., and Yannet, H. The total electrolyte content of animals and its probable relation to the distribution of body water. J. Biol. Chem., 1936, 113, 515. 
5. Heppel, L. A., The diffusion of radioactive sodium into the muscles of potassium-deprived rats. Am. J. Physiol., 1940, 128, 449.

6. Manery, J. F., and Hastings, A. B., The distribution of electrolytes in mammalian tissues. J. Biol. Chem., 1939, 127, 657.

7. Kaltreider, N. L., Meneely, G. R., Allen, J. R., and Bale, W. F., Determination of the volume of the extracellular fluid of the body with radioactive sodium. J. Exper. Med., 1941, 74, 569.

8. Amberson, W. R., Nash, T. P., Mulder, A. G., and Binns, D., The relationship between tissue chloride and plasma chloride. Am. J. Physiol., 1938, 122, 224.

9. Wallace, G. B., and Brodie, B. B., The distribution of administered bromide in comparison with chloride and its relation to body fluids. J. Pharmacol. \& Exper. Therap., 1939, 65, 214.

10. Weir, E. G., and Hastings, A. B., The distribution of bromide and chloride in tissues and body fluids. J. Biol. Chem., 1939, 129, 547.

11. Crandall, L. A., Jr., and Anderson, M. X., Estimation of the state of hydration of the body by the amount of water available for the solution of sodium thiocyanate. Am. J. Digest. Dis. \& Nutrition, 1934, 1, 126.

12. Lavietes, P. H., Bourdillon, J., and Klinghoffer, K. A., The volume of the extracellular fluids of the body. J. Clin. Invest., 1936, 15, 261.

13. Rosenbaum, J. D., and Lavietes, P. H., Lipoid-thiocyanate in serum. J. Biol. Chem., 1939, 131, 663.

14. Elkinton, J. R., and Taffel, M., The apparent volume of distribution of sulfocyanate and of sulfanilamide in the dog. Am. J. Physiol., 1942, 138, 126.

15. Overman, R. R., Permeability alterations in disease. J. Lab. \& Clin. Med., 1946, 31, 1170.

16. Overman, R. R., and Feldman, H. A., The effect of fatal $P$. Knowlesi malaria on simian circulatory and body fluid compartment physiology. J. Clin. Invest., 1947, 26, 1049.

17. Overman, R. R., Tharp, C. P., and Tuttle, A. H., Alterations in fluid and ionic distribution in various patho-physiologic conditions. Federation Proc., 1948, 7, 89.

18. Newman, E. V., Bordley, J., and Winternitz, J., The interrelationships of glomerular filtration rate (mannitol clearance), extracellular fluid volume, surface area of the body and plasma concentration of mannitol. Bull. Johns Hopkins Hosp., 1944, 75, 253.

19. Elkinton, J. R., The volume of distribution of mannitol as a measure of the volume of extracellular fluid, with a study of the mannitol method. J. Clin. Invest., 1947, 26, 1088.

20. Dominguez, R., Corcoran, A. C., and Page, I. H., Mannitol: Kinetics of distribution, excretion and utilization in human beings. J. Lab. \& Clin. Med., 1947, 32, 1192.
21. Kruh $\varnothing f f e r, P$., Inulin as an indicator for the extracellular space. Acta physiol. Scandinav., 1946, 11, 16.

22. Kruhфffer, P., The significance of diffusion and convection for the distribution of solutes in the interstitial space. Acta physiol. Scandinav., 1946, 11, 37.

23. Gaudino, M., Schwartz, I. L., and Levitt, M. F., Inulin volume of distribution as a measure of extracellular fluid in dog and man. Proc. Soc. Exper. Biol. \& Med., 1948, 68, 507.

24. Gaudino, M., and Levitt, M. F., Inulin space as a measure of extracellular fluid. Amer. J. Physiol., 1949, 157, 387.

25. Brodie, B. B., and Friedman, M. M., The determination of bromide in tissues and biological fluids. J. Biol. Chem., 1938, 124, 511.

26. Harrison, H. E., A modification of the diphenylamine method for determination of inulin. Proc. Soc. Exper. Biol. \& Med., 1942, 49, 111.

27. Alving, A. S., Rubin, J., and Miller, B. F., A direct colorimetric method for the determination of inulin in blood and urine. J. Biol. Chem., 1939, 127, 609.

28. Westfall, B. B., and Landis, E. M., The molecular weight of inulin. J. Biol. Chem., 1936, 116, 727.

29. Bunim, J. J., Smith, W. W., and Smith, H. W., The diffusion coefficient of inulin and other substances of interest in renal physiology. J. Biol. Chem., 1937, 118, 667.

30. Smith, Homer W., The Physiology of the Kidney. Oxford University Press, New York, 1937.

31. Unpublished data.

32. Berger, E. Y., and Dunning, M., personal communication.

33. Richards, A. N., Westfall, B. B., and Bott, P. A., Renal excretion of inulin, creatinine and xylose in normal dogs. Proc. Soc. Exper. Biol. \& Med., 1934, 32, 73.

34. Shannon, J. A., and Smith, H. W., The excretion of inulin, xylose and urea by normal and phlorizinized man. J. Clin. Invest., 1935, 14, 393.

35. Smith, W. W., Finkelstein, N., and Smith, H. W., Renal excretion of hexitols (Sorbitol, Mannitol and Dulcitol) and their derivatives (Sorbitan, Isomannide and Sorbide) and of endogenous creatinine-like chromogen in dog and man. J. Biol. Chem., 1940, 135, 231.

36. Berger, E. Y., Farber, S. J., and Earle, D. P., Personal communication.

37. Smith, P. K., Winkler, A. W., and Schwartz, B. M., The distribution of magnesium following the parenteral administration of magnesium sulfate. J. Biol. Chem., 1939, 129, 51.

38. Brodie, B. B., Brand, E., and Leshin, S., The use of bromide as a measure of extracellular fluid. $\mathrm{J}$. Biol. Chem., 1939, 130, 555.

39. Gregersen, M. I., and Stewart, J. D., Simultaneous determination of the plasma volume with $\mathrm{T}-1824$, and the "Available Fluid" volume with sodium thiocyanate. Am. J. Physiol., 1939, 125, 142. 
40. Manery, J. F., and Haege, L. F., The extent to which radioactive chloride penetrates tissues and its significance. Am. J. Physiol., 1941, 134, 83.

41. Soberman, R., Brodie, B. B., Levy, B. B., Axelrod, J., Hollander, V., and Steele, J. M., The use of antipyrine in the measurement of total body water in man. J. Biol. Chem., in press.
42. Hollander, V., Cotui, F., and Chang, P., Deuterium oxide and thiocyanate spaces in protein depletion. J. Lab. and Clin. Med., in press.

43. Berger, E. Y., Farber, S. J., and Earle, D. P., Jr., Comparison of the constant infusion and urine collection techniques for the measurement of renal function. J. Clin. Invest., 1948, 27, 710. 